\title{
Potential preventive effect of Lactobacillus acidophilus and Lactobacillus plantarum in patients with polyps or colorectal cancer
}

\author{
Nazi ZINATIZADEH ${ }^{1}$, Farzad KHALILI' ${ }^{2}$, Parviz FALLAH ${ }^{3}$, Malihe FARID ${ }^{4,5}$, \\ Maryam GERAVAND ${ }^{1}$ and Somayeh YASLIANIFARD ${ }^{6,7}$
}

ABSTRACT - Background - Colorectal cancer is one of the major causes of death worldwide. Many studies have been done on the biology of its formation as well as its treatment in recent years. One of the factors involved in the formation or treatment of this malignancy can be attributed to the microbial flora in the intestine. Objective - This study investigate the potential preventive effect of Lactobacillus acidophilus and Lactobacillus plantarum in patients with polyps or colorectal cancer (CRC). Methods - A total of 77 samples were selected in the form of three groups including individuals suffering from CRC, polyps and healthy subjects. Genomic DNA of fecal specimens and standard strains were extracted and amplified employing primers targeting of the 16S rRNA gene for initial detection. Absolute Real Time PCR quantification was used to determine the copy of the bacterial expression per gram of feces. Results - No significant difference were observed between age and gender in the mentioned groups $(P=0.06)$. The average copy number of Lactobacillus acidophilus shows Significant difference between the healthy group and those with polyps $(P<0.0001)$, the healthy group and those with colorectal cancer $(P<0.0001)$, as well as those with polyps and the colorectal cancer patients $(P<0.0001)$. Conclusion - These results may indicate that taking Lactobacillus acidophilus in people with a family history of CRC and people with polyps may be a way of preventing, treating or reducing the severity of CRC.

HEADINGS - Colorectal neoplasms. Polyps. Probiotics. Lactobacillus acidophilus, Lactobacillus plantarum.

\section{INTRODUCTION}

Colorectal cancer (CRC) is one of the leading causes of mortality in the world, which has grown significantly in recent years, may cause to malignancy ${ }^{(1)}$.

The presence of polyps in the inner wall of the colon is a highrisk complication for the development of $\mathrm{CRC}^{(2)}$. Adenoma is the most common and important type of colon polyps, and it is the basis for the creation of tumors in the colon. The prevalence of this disorder is directly related to aging, and in countries with high prevalence, such as United States, fifty to sixty five percent of the population over 65 years old have Adenoma $^{(3-5)}$.

The incidence of CRC in Iran is lower than that of western countries. It is the fifth most common diagnostic cancer in Iranian men and women population respectively ${ }^{(6)}$. Statistics show that the incidence of illness in our country has increased over the past 25 years ${ }^{(7)}$. Recent studies in Iran have also shown that about 43 percent of patients with CRC are under the 50 years old ${ }^{(8)}$.

Effective factors in CRC include genetic and environmental factors. Environmental factors in this disease are more important than genetic factors. The environmental factors including inappropriate diets such as high fat, low fiber, and low carbohydrates ${ }^{(9,10)}$.
Direct statistical correlation between germs and cancer has been identified $^{(11)}$, for example, Fusobacterium and Escherichia coli are now recognized as a primary cause of peptic ulcers and gastric cancers $^{(12,13)}$

Intestinal microbiota in human consists of two major phyla of Bacteroides and Firmicutes ${ }^{(14)}$. In the intestinal flora there are two kinds of beneficial and harmful types of bacteria. Intestinal microbiota has different roles, including intestinal health, immune system modification, presence of drug metabolism, decomposition of carcinogenic factors, vitamin production, fermentation, electrolyte absorption, and epithelial cell growth, preventing the accumulation of pathogenic bacteria such as Escherichia coli and Clostridium in the intestines and preventing allergies ${ }^{(15)}$.

Probiotics are living organisms that, have an effect on the health of the host by affecting the microbial flora. Probiotics often belong to the human intestinal microbial flora. There is a belief in probiotics that the microbial flora of the intestine has a protective effect against disease. The protective role of probiotics is effective when treated as a microbial flora in the Intestine ${ }^{(16)}$. The Lactobacillaceae family is one of the most important probiotics. This family consists of gram positive, catalase-negative and non-sporulated rods. Although there are many bacteria that have probiotic prop-

Declared conflict of interest of all authors: none

Disclosure of funding: This project was financially supported by Alborz University of Medical Sciences, Karaj, Iran

Alborz University of Medical Sciences, School of Medicine, Student Research Committee, Karaj, Iran. ${ }^{2}$ Alborz University of Medical Sciences, Liver and Gastrointestinal Disease Research Center Karaj, Iran ${ }^{3}$ Alborz University of Medical Sciences, School of Paramedical Sciences, Department of Hematology Karaj, Iran. ${ }^{4}$ Alborz University of Medical Sciences, Social Determinants of Health Research Center, Karaj, IR Iran. ${ }^{5}$ Alborz University of Medical Sciences, Faculty of Medicine, Karaj, IR Iran. ${ }^{6}$ Alborz University of Medical Sciences, School of Medicine, Department of Microbiology, Karaj, Iran. ${ }^{7}$ Alborz University of Medical Sciences, Dietary Supplements and Probiotic Research Center, Karaj, Iran.

Corresponding author: Somayeh Yaslianfard. Orcid: 0000-0001-8423-0652. E-mail: syaslianifard@gmail.com 
erties $^{(17)}$, but Lactobacillus and Bifidium can be mentioned as the most common probiotics in digestive tract and play an important role in the treatment of the digestive disease ${ }^{(18)}$.

This study, for the first time aimed to determine the mean population of Lactobacillus acidophilus and Lactobacillus plantarum in patients with polyps or CRC in comparison of healthy peoples to investigate the potential preventive effect of these bacteria on polyps or development of colorectal cancer.

\section{METHODS}

\section{Sampling}

Healthy peoples, individuals with polyps or CRC were diagnosed by a gastroenterologist using colonoscopy. CRC positive cases were confirmed by histopathology test. A total of 77 samples were selected in the form of three groups of 25 people including individuals suffering from CRC, 28 polyps and 24 healthy subjects, respectively. Exclusion criteria were a personal history of CRC, IBD or IBS and regular use of non-steroidal anti-inflammatory drugs (NSAIDS), statins, or probiotics. Patients did not receive antibiotics for one month before surgery. Fecal specimens were transported to the laboratory on ice and frozen at $-80^{\circ} \mathrm{C}$.

\section{Preparation of standard strain}

Standard strains of Lactobacillus acidophilus (DSM20079) and Lactobacillus plantarum (DSM20174) were prepared from the Iranian Biological Resource Center (IBRC). These strains were cultured in MRS agar and MRS broth media for 48 hours, then a suspension cultures of bacteria was prepared for isolation of genomic DNA.

\section{Genomic DNA extraction}

Genomic DNA of fecal specimens and standard strains were extracted using Qia amp DNA stool mini kit (Qiagen) and the tissue genomic DNA extraction mini kit (Favorgen Biotech Corp), According to the manufacturer's instructions, respectively. Integrity size of DNA were checked by $0.1 \%$ agarose gel electrophoresis. DNA concentrations were determined with the Nano Drop 2000 (Thermo. Scientific) and stored at $-20^{\circ} \mathrm{C}$ prior to amplification steps.

\section{Polymerase chain reaction (PCR)}

Extracted DNA was amplified employing primers targeting of the 16S rRNA gene. Forward and reverse primers for Lactobacillus acidophilus and Lactobacillus plantarum were 5' - AATTCTCTTCTCGGTCGCTCTA-3'; 5'-CCTTTCTAAGGAAGCGAAGGAT-3', and 5'-TTACCTAACGGTAAATGCGA-3'; 5'-GCCGCCTAAGGTGGGACAGAT-3' respectively. The specificity of the primers was confirmed by PCR in $25 \mu \mathrm{L}$ reaction mixtures containing $2.5 \mu \mathrm{L}$ reaction buffer, $2 \mu \mathrm{L}$ of template, $1 \mu \mathrm{L}$ (each) primer, $1 \mu \mathrm{L}$ DNTP (mix), $0.5 \mu \mathrm{L}$ Taq polymerase, $2 \mu \mathrm{L}$ DNA- template, $1 \mu \mathrm{L} \mathrm{Mgcl} 2$. PCR was performed with an initial denaturation step of $94^{\circ} \mathrm{C}$ for $5 \mathrm{~min}$, followed by 30 cycles of $94^{\circ} \mathrm{C}$ for $1 \mathrm{~min}$, and $55^{\circ} \mathrm{C}$ for $30 \mathrm{~s}$.

$10 \mu \mathrm{L}$ of the PCR was subjected to electrophoresis on a $2 \%$ agarose gel containing Gelred, and the DNA bands were visualized by UV illumination to confirm the generation of 176-bp (Lactobacillus acidophilus), 166-bp (Lactobacillus plantarum) amplicons.

\section{Real-time quantification PCR of total Lactobacillus acidophilus and Lactobacillus plantarum load}

Quantitative RT-PCRs were performed in a reaction volume of $20 \mu \mathrm{L}$ containing $10 \mu \mathrm{L}$ SYBR Green PCR Master Mix, $1 \mu \mathrm{L}$ each of the forward and reverse primers, $2 \mu \mathrm{L}$ rox and $2 \mu \mathrm{L}$ of DNA extracted from the fecal samples. The amount of DNA in the 77 fecal samples was determined in duplicate, and the mean values were calculated. Amplification and detection of DNA were performed with the LightCycler\&reg; 96 Real-Time PCR System - Roche Life Science. The reaction conditions were $95^{\circ} \mathrm{C}$ for $2 \mathrm{~min}$ and $95^{\circ} \mathrm{C}$ for $5 \mathrm{~s}$, followed by 40 cycles of $95^{\circ} \mathrm{C}$ for 15 $\mathrm{s}$ and $55^{\circ} \mathrm{C}$ for $10 \mathrm{~s}$. Data analysis was conducted with sequence detection software lightcycler 96. Purified genomic DNA in the range $1 \mathrm{ng}$ of Lactobacillus acidophilus and Lactobacillus plantarum were used as the standard for determining the amount of Lactobacillus acidophilus and Lactobacillus plantarum DNA by real-time PCR (FIGURE 1).

Absolute quantification was used to determine the copy of the bacterial expression per gram of feces using LightCycler $^{\circledR} 96$. In the sample editor section, at least three concentrations were

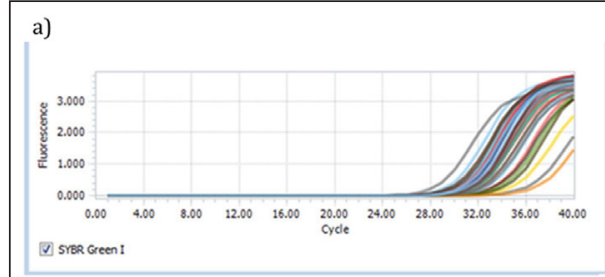

d)

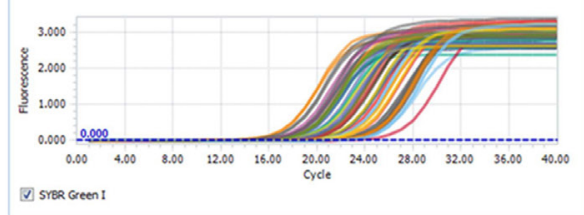

b)

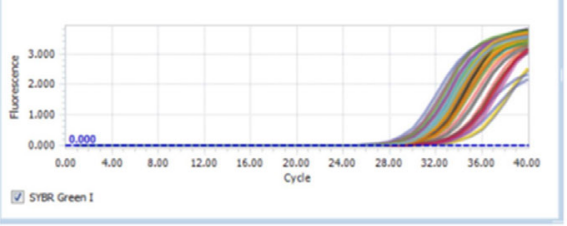

e)

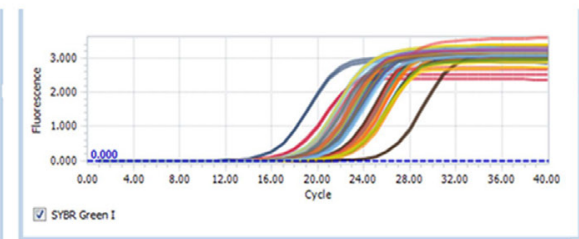

c)

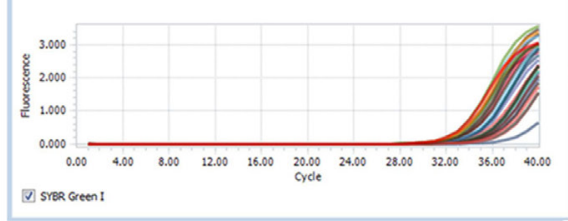

f)

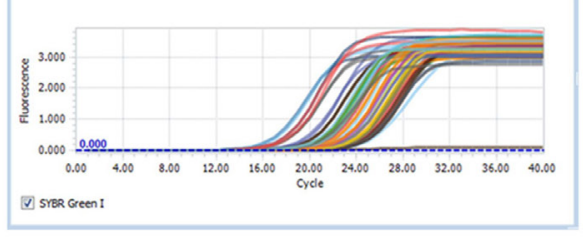

FIGURE 1. Real-time quantification PCR graphs of total bacterial loada. a) Lactobacillus acidophilus-healthy control, b) Lactobacillus acidophilus-polyps, c) Lactobacillus acidophilus- colorectal cancer, d) Lactobacillus plantarum-healthy control, e) Lactobacillus plantarum- polyps, f) Lactobacillus plantarumcolorectal cancer. 
selected from the standard strains, and the copy number of the bacteria per gram of feces were determined in each sample based on the standard curves.

\section{Statistical analysis}

Descriptive data were analyzed with the Statistical Package for the Social Sciences 21 (SPSS 21). Chi- square, Mann-Whitney Test and Kruskal-Wallis Test were applied for data analysis. $P$ values of $<0.05$ were considered significant.

\section{RESULTS}

\section{Sampling and demographic analysis}

Using ANOVA statistical test no significant difference was found between the ages of the studied groups $(P=0.06)$. In addition no significant difference were observed between gender in the mentioned groups $(P=0.06)$. The age range of $55-65$ years included the highest number of polyps and CRC, in addition the results of statistical analysis showed that the frequency of $\mathrm{O}$ blood group is higher in patients with polyps and CRC $(P<0.05)$. There were no significant differences in the other variables (TABLE 1).

TABLE 1. Demographic data recorded for each study participant included age, blood group, and smoking.

\begin{tabular}{lcccc}
\hline Variables & $\begin{array}{c}\text { Healthy } \\
\text { N (\%) }\end{array}$ & $\begin{array}{c}\text { Polyps } \\
\text { N (\%) }\end{array}$ & $\begin{array}{c}\text { Cancer } \\
\text { N (\%) }\end{array}$ & $P$-value \\
\hline Smoking & $5(17.9)$ & $9(14.3)$ & $8(28.6)$ & 0.68 \\
Age & $52 \pm 8$ & $57 \pm 9$ & $58 \pm 9$ & 0.06 \\
A blood group & $5(17.9)$ & $6(21.4)$ & $6(21.4)$ & 0.12 \\
B blood group & $10(35.7)$ & $4(14.3)$ & $4(14.3)$ & 0.14 \\
AB blood group & $6(21.4)$ & $4(14.3)$ & $4(14.3)$ & 0.07 \\
O blood group & $7(25)$ & $14(50)$ & $14(50)$ & 0.00 \\
Fat-rich diet & $11(39.3)$ & $9(32.1)$ & $16(57.1)$ & 0.15 \\
\hline
\end{tabular}

\section{Specimens and DNA isolation}

To better demonstrate the distribution of bacterial DNA in samples taken from healthy peoples and those with polyps or CRC, the percentage of those carrying bacterial DNA was measured. All samples of healthy people and those with polyps contained DNA of Lactobacillus acidophilus. However, $86 \%$ of the subjects with CRC had DNA of Lactobacillus acidophilus. 100\% of samples had Lactobacillus plantarum DNA.

\section{Real-time quantification PCR of total Lactobacillus acidophilus and Lactobacillus plantarum load}

The average copy number of Lactobacillus acidophilus was calculated in three groups studied $(P<0.0001)$. A statistically significant difference was found between the healthy group and those with polyps, the healthy group and those with colorectal cancer, as well as those with polyps and the colorectal cancer patients (TABLE 2).

Average copy number of Lactobacillus plantarum was calculated in three groups and There was no significant difference between the three groups $(P>0.05)$ (TABLE 3$)$.
TABLE 2. Average copy number of Lactobacillus acidophilus in each groups.

\begin{tabular}{|c|c|c|c|c|}
\hline $\begin{array}{l}\text { Studied } \\
\text { groups }\end{array}$ & $\begin{array}{c}\text { Average } \\
\text { (copy number per } \\
\text { gram feces } \pm \text { SD) }\end{array}$ & $\begin{array}{c}\text { Total } \\
P \text {-value }\end{array}$ & & $P$-value \\
\hline Healthy & $\begin{array}{c}2.2501 \times 10^{10} \pm \\
1.2591 \times 10^{7}\end{array}$ & \multirow{3}{*}{$<0.0001$} & $\begin{array}{c}\text { Healthy / } \\
\text { polyps }\end{array}$ & $<0.0001$ \\
\hline Polyp & $\begin{array}{c}8.7742 \times 10^{8} \pm \\
2.3760 \times 10^{8}\end{array}$ & & $\begin{array}{l}\text { Healthy/ } \\
\text { câncer }\end{array}$ & $<0.0001$ \\
\hline Cancer & $\begin{array}{c}2.4323 \times 10^{6} \pm \\
1.2591 \times 10^{6}\end{array}$ & & $\begin{array}{l}\text { Polyps / } \\
\text { câncer }\end{array}$ & $<0.0001$ \\
\hline
\end{tabular}

TABLE 3. Average copy number of Lactobacillus plantarum in each groups.

\begin{tabular}{lcc}
\hline $\begin{array}{l}\text { Studied } \\
\text { groups }\end{array}$ & $\begin{array}{c}\text { Average } \\
(\text { copy number per gram feces } \pm \mathrm{SD})\end{array}$ & $\begin{array}{c}\text { Total } \\
\boldsymbol{P} \text {-value }\end{array}$ \\
\hline Healthy & $3.2 \times 10^{11} \pm 17 \times 10^{9}$ & \\
Polyps & $3.0 \times 10^{10} \pm 12 \times 10^{9}$ & 0.133 \\
Cancer & $5.0 \times 10^{10} \pm 10 \times 10^{9}$ & \\
\hline
\end{tabular}

\section{DISCUSSION}

The number of bacteria estimated by the molecular techniques is greater than the total bacterial load detected by culture methods, demonstrating the utility of real-time PCR in the analysis of the bacterial load ${ }^{(19)}$.

So far, no study has been done to determine the population of Lactobacillus acidophilus and Lactobacillus plantarum in patients with CRC and polyps. Therefore, the present study was conducted to determine the copy number of Lactobacillus acidophilus and Lactobacillus plantarum from fecal specimens of patients with polyps and CRC in comparison with control group. In this study, for the first time, Cyber Green method was used to check the copy of these two bacteria per gram of feces. According to the results of this study, The mean copy number of Lactobacillus acidophilus decreased in people with CRC compared to healthy subjects and people with polyps, Also, The mean of copy number of this bacterium is lower in people with polyps in comparison of healthy people.

Significant difference in the mean copy number of Lactobacillus plantarum in three groups was not observed. There are a variety of reasons, for example Lactobacillus acidophilus is one of the most important and most frequent colon flora and it may change faster than the changes in bowel conditions affected by polyps and CRC.

Studies indicate that the population of intestinal bacteria is different between healthy subjects and people with $\mathrm{CRC}^{(2)}$. For example, researches have shown that in patients with CRC, the population of some bacteria such as Escherichia, Citrobacter, Shigella Flavobacterium, Acinetobacter and Chryseobacterium decreased ${ }^{(21)}$.

Intestinal bacteria play different roles in inducing disease or protecting individuals. Some species exacerbate the formation of a tumor and cause cancer, while others contribute to the health of the intestine. For example, Eubacterium rectal and Eubacterium eligens are firmicutes, which have a significant correlation with CRC. While the intestinal proteobacteria population declines in patients with $\mathrm{CRC}^{(22)}$.

Although most cases of CRC occur individually, the role of inherited genetic factors in the development of CRC is $35 \%$. The first-degree relatives of CRC patients are at increased risk of developing CRC, with a relative risk of 2.2. This risk is strongly correlated with the number of affected family members, For example, in a family with two or more people with colorectal cancer, the relative risk for the other family members increases to 4 . In 
addition the relative risk of developing adenoma or CRC in people with a history of adenoma in their family increases to 2 folds ${ }^{(23)}$.

There is evidence that treatment with probiotics may modulate gastrointestinal function and reduce digestive disorders ${ }^{(24)}$. Fermented products such as short chain fatty acids (SCFA) are produced by the consumption of probiotics ${ }^{(25)}$. Probiotics in the mouse colon have been shown to induce a protective glutathione transferases II enzyme. These factors reduce the burden of the genotoxic substances in the intestine and also increases the production of factors that disable toxic compounds, for example Butyrate is one of these protective factors that slows the propagation of cancer cells ${ }^{(26)}$. It was also observed that abundance of Bacteroides and Bifidobacteria was associated with a reduction in the risk of colon polyps ${ }^{(27)}$.

Considering the results obtained in this study as well as using the results of previous studies, it can be concluded that after the diagnosis of adenomatous polyps, doctors can prescribe probiotics to treat or prevent CRC. Older people can probably prevent the development of polyps or their progression to malignancy by including probiotics in their diet.

In this study, there is a significant difference in blood groups, so that in the blood group $\mathrm{O}$, the number of people with polyps and $\mathrm{CRC}$ is more than other groups. It can be argued that colon cancer is more likely to occur in those who have a blood type $\mathrm{O}$ and they can prevent the disease by using a proper diet and taking probiotics. Periodic screening can be helpful to assess, diagnose and treat the disease at the early stages. Significant difference between smoking and CRC was not observed.

\section{CONCLUSION}

CRC is one of the leading causes of mortality in the world, which has grown significantly in recent years, and may cause to malignancy. In this study, there was a significant difference in population of Lactobacillus acidophilus bacteria in patients with polyps, CRC and healthy subjects. However, no significant difference was found in the three groups in the study of Lactobacillus plantarum population. These results may indicate the Potential preventive effect of Lactobacillus acidophilus in people with a family history of CRC. In addition, this bacterium may be used as a supplement to patients with intestinal polyps in the future. Further studies are needed to confirm the preventive or therapeutic role of this bacterium.

\section{ACKNOWLEDGEMENT}

We thank the Staff of Bahonar Hospital in Alborz Province for providing the fecal samples that were used in this study.

\section{Authors' contribution}

Zinatizadeh N; laboratory expriments, data analysis and writing of the manuscript. Khalili F; study design, clinical diagnosis and sampling. Fallah P; laboratory expriments and data analysis. Farid M; data analysis. Geravand M; laboratory expriments. Yaslianifard $\mathrm{S}$; study design, laboratory expriments, data analysis and writing of the manuscript.

Zinatizadeh N, Khalili F, Fallah P, Farid M, Geravand M, Yaslianifard S. Arq Gastroenterol. Potencial efeito preventivo do Lactobacillus acidophilus e Lactobacillus plantarum em pacientes com pólipos ou câncer colorretal. Arq Gastroenterol. 2018;55(4):407-11.

RESUMO - Contexto - O câncer colorretal é uma das principais causas de morte em todo o mundo. Muitos estudos têm sido feitos sobre a biologia de sua formação, bem como o seu tratamento nos últimos anos. Um dos fatores envolvidos na formação ou no tratamento desta malignidade pode ser atribuído à flora microbiana no intestino. Objetivo - Este estudo investigou o potencial efeito preventivo de Lactobacillus acidophilus e Lactobacillus plantarum em pacientes com pólipos ou câncer colorretal (CCR). Métodos - Um total de 77 amostras foram selecionadas e três grupos foram formados, a saber, indivíduos portadores de CCR, pólipos e indivíduos saudáveis. O DNA genomico de espécimes fecais e de amostras padrão foi extraído e amplificado empregando primers que focalizaram o gene do rRNA 16S para a deteção inicial. A quantificação do PCR em tempo real absoluto foi utilizada para determinar a cópia da expressão bacteriana por grama de fezes. Resultados - Não foram observadas diferenças significativas entre idade e sexo nos grupos citados $(P=0,06)$. O número médio de cópias de Lactobacillus acidophilus mostra diferença significativa entre o grupo saudável e aqueles com pólipos $(P<0,0001)$, o grupo saudável e aqueles com câncer colorretal $(P<0,0001)$, bem como aqueles com pólipos e câncer colorretal pacientes $(P<0,0001)$. Conclusão - Estes resultados podem indicar que a ingestão de Lactobacillus acidophilus em pessoas com antecedentes familiares de CCR e pessoas com pólipos pode ser uma forma de prevenir, tratar ou reduzir a gravidade da CCR.

DESCRITORES - Neoplasias colorretais. Pólipos. Probióticos. Lactobacillus acidophilus. Lactobacillus plantarum.

\section{REFERENCES}

1. Uhry Z, Belot A, Colonna M, Bossard N, Rogel A, Iwaz J, et al. National cancer incidence is estimated using the incidence/mortality ratio in countries with local incidence data: is this estimation correct? Cancer Epidemiol. 2013;37:270-7.

2. Simon K. Colorectal cancer development and advances in screening. Clin Interv Aging. 2016;11:967-76.

3. Rickert RR, Auerbach O, Garfinkel L, Hammond EC, Frasca JM. Adenomatous lesions of the large bowel: an autopsy survey. Cancer. 1979;43:1847-57.

4. Gordillo J, Zabana Y, Garcia-Planella E, Manosa M, Llao J, Gich I, et al. Prevalence and risk factors for colorectal adenomas in patients with ulcerative colitis. United European Gastroenterol J. 2018;6:322-30.

5. Chablani SV, Jandorf L, DuHamel K, Lee KK, Sriphanlop P, Villagra C, et al. Adenoma Prevalence and Distribution Among US Latino Subgroups Undergoing Screening Colonoscopy. Dig Dis Sci. 2017;62:1637-46.
6. Moghimi-Dehkordi B, Safaee A, Zali MR. Prognostic factors in 1,138 Iranian colorectal cancer patients. Int J Colorectal Dis. 2008;23:683-8.

7. Azadeh S, Moghimi-Dehkordi B, Fatem SR, Pourhoseingholi MA, Ghiasi S, Zali MR. Colorectal cancer in Iran: an epidemiological study. Asian Pac J Cancer Prev. 2008;9:123-6.

8. Yazdizadeh B, Jarrahi AM, Mortazavi H, Mohagheghi MA, Tahmasebi S, Nahvijo A. Time trends in the occurrence of major GI cancers in Iran. Asian Pac J Cancer Prev. 2005;6:130-4.

9. Kiss I, Sandor J, Pajkos G, Bogner B, Hegedus G, Ember I. Colorectal cancer risk in relation to genetic polymorphism of cytochrome P450 1A1, 2E1, and glutathione-S-transferase M1 enzymes. Anticancer Research. 2000;20:519-22.

10. Lee S-M, Lee W-K. Inhibitory effects of lactic acid bacteria (LAB) on the azoxymethane-induced colonic preneoplastic lesions. J Microbiol. 2000;38:169-75. 
11. Jandhyala SM, Talukdar R, Subramanyam C, Vuyyuru H, Sasikala M, Nageshwar Reddy D. Role of the normal gut microbiota. World J Gastroenterol. 2015;21:8787-803.

12. Zackular JP, Rogers MA, Ruffin MTt, Schloss PD. The human gut microbiome as a screening tool for colorectal cancer. Cancer Prev Res (Phila). 2014;7:1112-21.

13. Guerra L, Guidi R, Frisan T. Do bacterial genotoxins contribute to chronic inflammation, genomic instability and tumor progression? FEBS J. 2011;278:4577-88.

14. Cukrowska B, Sowinska A, Bierla JB, Czarnowska E, Rybak A, Grzybowska-Chlebowczyk U. Intestinal epithelium, intraepithelial lymphocytes and the gut microbiota - Key players in the pathogenesis of celiac disease. World $\mathbf{J}$ Gastroenterol. 2017;23:7505-18.

15. Hooper LV, Midtvedt T, Gordon JI. How host-microbial interactions shape the nutrient environment of the mammalian intestine. Annu Rev Nutr. 2002;22:283-307.

16. Stanton C, Gardiner G, Meehan H, Collins K, Fitzgerald G, Lynch PB, et al. Market potential for probiotics. Am J Clin Nutr. 2001;73(Suppl 2):476S-83S.

17. de Roos NM, Katan MB. Effects of probiotic bacteria on diarrhea, lipid metabolism, and carcinogenesis: a review of papers published between 1988 and 1998. Am J Clin Nutr. 2000;71:405-11.

18. Russo F, Linsalata M, Orlando A. Probiotics against neoplastic transformation of gastric mucosa: effects on cell proliferation and polyamine metabolism. World J Gastroenterol. 2014;20:13258-72.

19. Nadkarni MA, Martin FE, Jacques NA, Hunter N. Determination of bacterial load by real-time PCR using a broad-range (universal) probe and primers set. Microbiology. 2002;148:257-66.
20. Yu YN, Fang JY. Gut Microbiota and Colorectal Cancer. Gastrointest Tumors. 2015;2:26-32.

21. Mangan PR, Harrington LE, O'Quinn DB, Helms WS, Bullard DC, Elson CO, et al. Transforming growth factor-beta induces development of the $\mathrm{T}(\mathrm{H}) 17$ lineage. Nature. 2006:441:231-4.

22. Joly F, Mayeur C, Bruneau A, Noordine ML, Meylheuc T, Langella P, et al. Drastic changes in fecal and mucosa-associated microbiota in adult patients with short bowel syndrome. Biochimie. 2010;92:753-61.

23. van Wezel T, Middeldorp A, Wijnen JT, Morreau H. A review of the genetic background and tumour profiling in familial colorectal cancer. Mutagenesis. 2012;27:239-45

24. Ghoshal UC, Gwee KA, Holtmann G, Li Y, Park SJ, Simadibrata M, et al. The role of the microbiome and the use of probiotics in gastrointestinal disorders in adults in the Asia-Pacific region - background and recommendations of a regional consensus meeting. J Gastroenterol Hepatol. 2018;33:57-69.

25. Shen Z, Zhu C, Quan Y, Yuan W, Wu S, Yang Z, et al. Update on intestinal microbiota in Crohn's disease 2017: Mechanisms, clinical application, adverse reactions, and outlook. J Gastroenterol Hepatol. 2017;32:1804-12.

26. Abrahamse SL, Pool-Zobel BL, Rechkemmer G. Potential of short chain fatty acids to modulate the induction of DNA damage and changes in the intracellular calcium concentration by oxidative stress in isolated rat distal colon cells. Carcinogenesis. 1999;20:629-34.

27. Davis CD, Milner JA. Gastrointestinal microflora, food components and colon cancer prevention. J Nutr Biochem. 2009;20:743-52. 